\title{
Kitchen Market Monitoring in Bangladesh: A Study on Dhaka South City Corporation
}

\author{
Md. Mansur Hossen ${ }^{1}$ \\ ${ }^{1}$ Adjunct Faculty, Stamford University Bangladesh, Dhaka, Bangladesh \\ Correspondence: Md. Mansur Hossen, Adjunct Faculty, Stamford University Bangladesh, Dhaka, Bangladesh. \\ E-mail: mansurhossen82@gmail.com
}

Received: November 26, 2017 Accepted: December 27, 2017 Online Published: April 25, 2018

doi:10.5539/par.v7n1p26

URL: http://dx.doi.org/10.5539/par.v7n1p26

\begin{abstract}
Dhaka City Corporation (DCC) is the former self-governing corporation which is associated with the task of running the affairs of the city of Dhaka . According to the Local Government Act (Amendment), 2011, it is the mandatory function of City Corporation to show the price chart of daily necessities in front of market. Sellers are bound to follow this price chart. It is the right of citizens to bargain with seller to follow this chart. DSCC (Dhaka South City Corporation) acts as a watchdog in the market to follow the price chart. But unfortunately, price chart do not exist in many markets of DSCC jurisdiction. Although sometimes price chart exit but it is not updated regularly. In Bangladesh, every marketing sphere is controlled by a financially powered group. They are also considered as syndicate. They control each and every movements of market. The kitchen market is not out of their black hand. Therefore, it is obvious that every classes of customer need to go there for their own daily essential commodities. The price of daily essential commodities imposed by DCC is not followed by the sellers. Imposed price of DCC is not effective for customer unawareness and their indifferent attitude. Most of the time, it is impossible to pursue the imposed price although Government and its related administration department want to control it. The objectives of the study is to conduct a survey on the Bazaar monitoring system of DSCC and the effectiveness of the corporation to monitor the prices of daily necessities in a kitchen market. This research is mainly qualitative in nature. A stratified sampling method is followed for conducting this research. Data is collected from both primary and secondary sources. The primary data has been collected from four kitchen market (Polashi Bazaar,Ananda Bazaar,New Market Bazaar and Hatirpool Bazaar) under DSCC jurisdiction. Secondary sources of data are books, internet, journals, DSCC's acts, DSCC's annual reports and reports of different research organizations concerned with Bazaar monitoring.
\end{abstract}

Keywords: kitchen market, Dhaka city corporation, monitoring, price chart, local government, right to information

\section{Introduction}

Dhaka City Corporation (DCC) is the former self-governing corporation which is associated with the task of running the affairs of the city of Dhaka (UNDP,1996). The Corporation was dissolved by the Local Government (City Corporation) Amendment Bill 2011 on November 29, 2011, passed in the Parliament of Bangladesh, and formally ceased to exist on December 1, 2011, following the President's approval, making way for a Dhaka North and a Dhaka South city corporations. DSCC is bound to perform some basic functions to serve the city dwellers .Among various functions market monitoring is a basic function of DSCC. Bazaar monitoring system is an important phenomenon for every country like Bangladesh. Without proper Bazaar monitoring system, irregularities and mismanagement exist in a Bazaar. Kitchen market is a common form of market seen all over the world. A kitchen market is one of the most essential markets where everyone needs to go every day. Kitchen market (kacha Bazar) is common both in rural and urban area of Bangladesh. Price hiking, food adulterine, product syndicating and so many problems are becoming regular scenario in the Kitchen Markets including groceries. Consumers are being constantly affected by such problems. A large portion of citizens are not sufficiently aware of prices and purity of daily-used products. Government has an agenda of 'Right to Information Act' for making the citizens update on any issues. On the other hand, City Corporations are supposed to deliver basic urban services to the city dwellers. And they are entitled to perform some essential and emergency actions within its boundary. Of various actions Dhaka South City Corporation (DSCC) is prescribed 
to monitor and supervise the kitchen markets within its jurisdiction to ensure people's right to know any relevant information. Now the standing committee of DSCC for Bazaar monitoring is bestowed with 78 bazaars to monitor over within its jurisprudence (www.dscc.org.bd, accessed on 30/10/2014)) By the way, effective and meaningful monitoring system has become imperative for operation of kitchen markets in the transparent way.

\section{Methodology of the Study}

The study is mainly based on primary data. Secondary sources are also used. Survey Method is used to collect primary information. A stratified sampling method has been followed for conducting this research. The study has randomly selected three kitchen markets of DSCC jurisdiction. They are: Polashi Bazaar, Ananda Bazaar, New Market Bazaar. I have taken response from different age group from 20 to 60 years old. Primary sources of data were questionnaire, interview and discussion with respondents. A structured questionnaire with both open and close ended questions has been used in this survey. We have also observed the markets and respondent attitudes (sellers) to validate the study. Secondary sources of data were books, internet, journals, DSCC's acts, DSCC's annual reports and reports of different research organizations concerned with Bazaar monitoring.

\section{Literature Review}

The urgency of Bazaar monitoring in Bangladesh dated back to 1970s when government establishes Trading Corporation of Bangladesh (TCB) with promulgation of president order (TCB order, 1972). According to ACER (Agency for Cooperation of Energy Regulation) - Bazaar monitoring is to assess retail market competition with a view to identifying instances of best practice which improve market performance (ACER report, 2014 ). Bazaar monitoring is also best defined as 'Supervisory activities in progress to ensure market is on-course and on schedule in meeting the objectives and performance target (Business dictionary, 2014). In case of DSCC (Dhaka south city corporation) the responsibility of Bazaar monitoring is entitled with a designated standing committee (city corporation act, 2009). It is clearly defined in act under article 50 that there would be a standing committee to observe, monitor and control market price (city corporation act, 2009).

Beside government endeavor, there exist some civil society organizations working to protect consumers' right in terms of pure commodities price monitoring as prescribed by City Corporation (Kreta-Bhokta andoloner sharuph, 2007). In its publication $\mathrm{CAB}$ sees Bazaar monitoring as a system which is aimed at keeping the price stable and within the purchasing power (CAB research paper, 2005). Bazaar monitoring is conducted with a view to make necessary goods attainable to consumers and ensuring balance between demand and supply (TCB order1972). In consumers' right protection act, 2009 it is mentioned that if any individual sells something in over rate prescribed by any authority he is likely to be punished up to 1 year imprisonment and/or 50 thousands taka as fine. (Bdlaws.minlaw.gov.bd, 2014)

Consumer Association Bangladesh (CAB) has made an attempt to pursue DSCC in terms of Bazaar monitoring. The surveillance by $\mathrm{CAB}$ covers Street Food Vending, labels on products, tobacco consumption, BSTI certification marks, road accidents, level of consumers' awareness of their rights and obligations are also carried out. Surveillance and Monitoring on market prices and quality of essential commodities and services is one of the regular activities of $\mathrm{CAB}$ and is done with a view to pressurize the government to take appropriate measures against anti-social price-hike, food and commodity adulteration. (Consumerbd.org, 2014)

The government has enacted The Consumers Right Protection Act, 2009 for the protection of the rights of the consumers, prevention of anti-consumer right practices. For carrying out the purposes of this Act, there shall be a Council to be called the National Consumers' Right Protection Council. The functions of the Council shall be as follows:-

1) to formulate policy on the protection of the rights of the consumers for the purposes of this Act, and to give directions to the Director General and the District Committee to implement the policy;

2) to make necessary regulations for the purposes of this Act;

3) to consider and give opinion on any matter referred by the Government regarding the protection of the rights of the consumers;

4) to advise and cooperate with the Government in making necessary laws and administrative directions with a view to protecting and promoting the rights of the consumers;

5) to undertake necessary educational and promotional campaign to create public awareness regarding the rights of the consumers;

6) to take necessary steps to create public awareness regarding the usefulness of protecting the rights of 
the consumers and bad impact of anti-consumer right practices;

7) to conduct research on the rights of the consumers;

8) to observe and monitor the activities of the Directorate, the Director General and the District Committees; and

9) to take necessary step for performing the aforesaid responsibilities and duties.

For carrying out the purposes of this Act, there shall be a Directorate to be called the Directorate of National Consumers' Right Protection. The Director General may take all necessary actions as he deems expedient and necessary for the protection of the rights of the consumers, prevention of anti-consumer right practice, and disposal of the complaint against violation of the rights of the consumers. Some basic functions of the Directorate are:-

10) to monitor whether the standard quality of goods or services by the seller is being maintained and take necessary actions;

11) to monitor whether any goods or medicines are being adulterated and take necessary actions;

12) to monitor whether the date of manufacture and expiry of the goods, instruction and amount are inscribed on the label of such goods in the manner instructed under any Act or rules and take necessary actions;

13) to monitor whether any expired goods or medicines are being sold and take necessary actions.

If any person violates any obligation, imposed by any Act or rules, of displaying the price-list of goods by affixing it at a conspicuous place of his shop or organization, or to sell the expire goods shall be punished with imprisonment for a term not exceeding 1 (one) year, or with fine not exceeding Taka 50 (fifty) thousands, or with both.

There are two world wide Bazaar monitoring methods. Bazaar monitoring methods are ARB and CMA method. While ARB (Air resource board, California) suggests for having a designated market monitoring cell/group where aggrieved person can directly draw complain to it. Even a strategy to engaging government law counsel/adviser in its campaign to precede immediate legal action (Arb.ca.gov-2014).On the other hand CMA (The Competition and Markets Authority, UK) has another approach to market monitoring. It seeks for ensuring competition in among the sellers. CMA model also suggest for having a market reference group to who the sellers are accountable. (Gov.UK, 2014).

\section{Data Analysis}

\section{Responses from Buyers}

\subsection{Known about Bazaar Monitoring System}

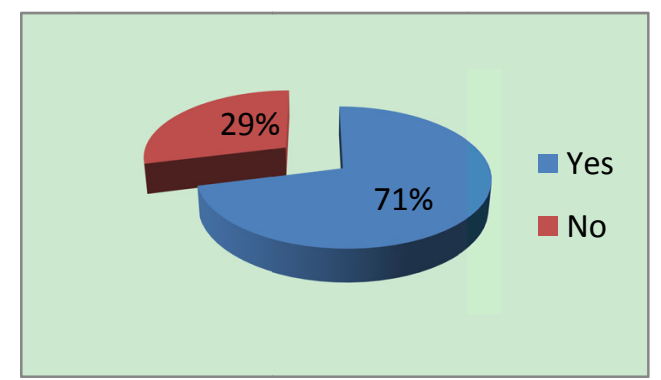

Figure1. Known about bazaar monitoring system

Most of the responedents $(71 \%, \mathrm{n}=32)$ known with Bazaar monitoring system of DSCC. Though media and academic text they know about market monitoring system. 29\% $(n=13)$ of the respondents never heard about this system. 


\subsection{Seeing Price Chart}

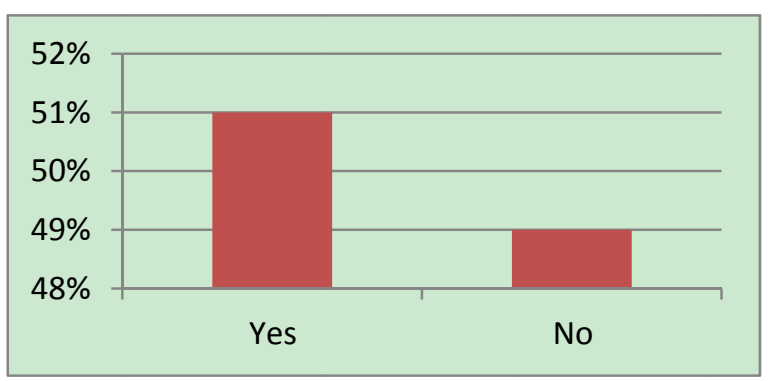

Figure 2. Seeing price chart

The figure 2 illustrates that $51 \%$ respondents have seen price chart of DSCC in the market. While $49 \%$ of the respondents have never seen any price chart in the market. Actually there is only a price chart in new market bazaar but there is no price chart in Polashi bazaar and Anondo bazaar. Most of the respondent who has seen the chart in grocery does not know that the chart is from DSCC or TCB.

\subsection{Frequency of Updating}

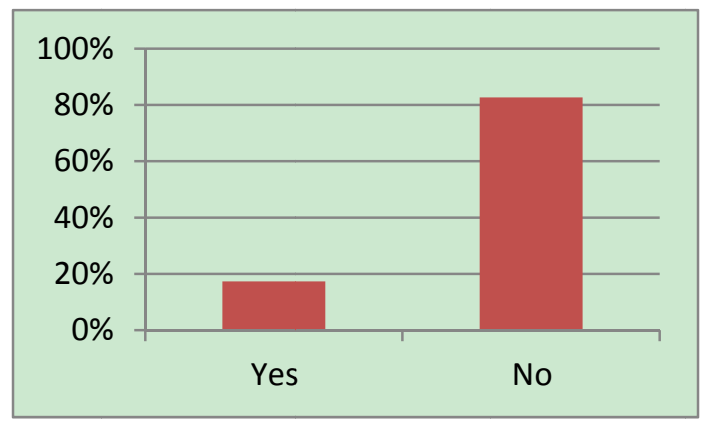

Figure 3. Frequency of updating

Only $17 \%$ of the respondent said that the price chart is updated regularly. Whilst $83 \%$ of the respondent have said that price chart is not updated regularly. They are appearing the prices of product is fixed on the chart from long time. Some respondents have said that they have not seen even to update the chart in Holy Romadan.

\subsection{Watching Expired Date of Commodities}

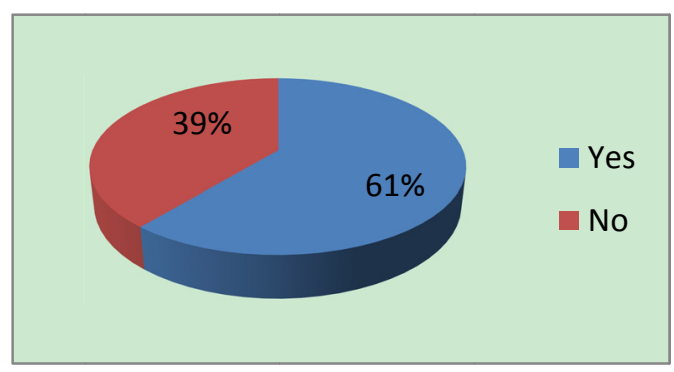

Figure 4. Watching expired date of commodities

It is the responsibility of bazaar monitoring committee to see whether the expired products are sold in the market. $61 \%$ of the respondents check the expired date of product. If they found any expired product they returned it to the seller. On the other hand, $39 \%$ of the respondents do not check the expired date of the product. 


\subsection{Receiving Voucher}

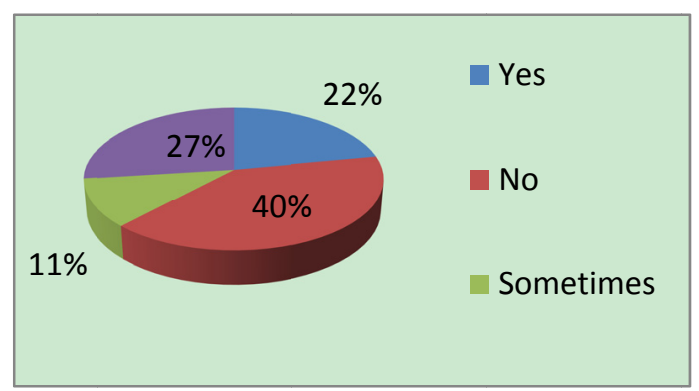

Figure 5. Receiving voucher

Voucher is one of the tools of monitoring. $22 \%$ of the respondents said that they receive voucher from sellers as a document of shopping. On the other hand, $40 \%$ of the respondent do not receive voucher from sellers. They think it is useless. $11 \%$ of the respondents receive voucher sometimes if sellers provide it willingly. They do not create pressure on seller for voucher.

4.6 Bargaining with Sellers to Follow Price Chart

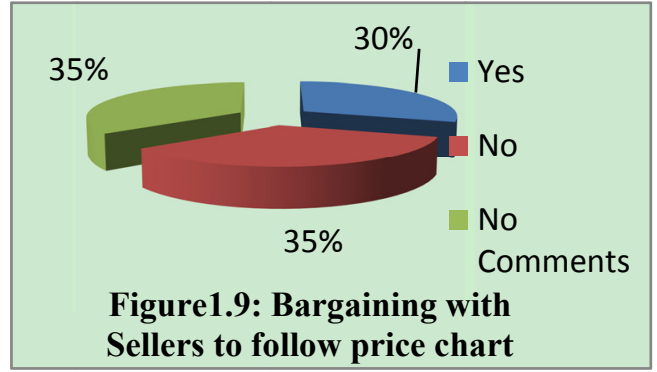

Figure 6. Bargaining with sellers

Bargaining with sellers is the right of customer's .Only $30 \%$ of the respondents bargain with sellers to follow the chart. On the other hand, $35 \%$ the respondents do not bargain with sellers. They said that they have not much time to bargain with sellers. $35 \%$ of the respondents do not fell any interest to answer this question.

\subsection{Steps When Claim over Price}

Claiming over price is common in our country. Most of vendors of kitchen market claim over price of a commodity. Customers show different behavior when the vendors claim over price. Such as:

1) Most of the respondents bargain with vendors or sellers

2) Some respondents do not bargain with sellers because they think that they do not have more time to bargain.

3) Some respondents do not purchase the product when seller claims over price.

4) Some respondents answer the question very simply "Take it"

5) Only a few number of respondents protest against over price.

6) Few respondents think that the vendors do not claim over price. 


\subsection{Witnessing DSCC Campaign}

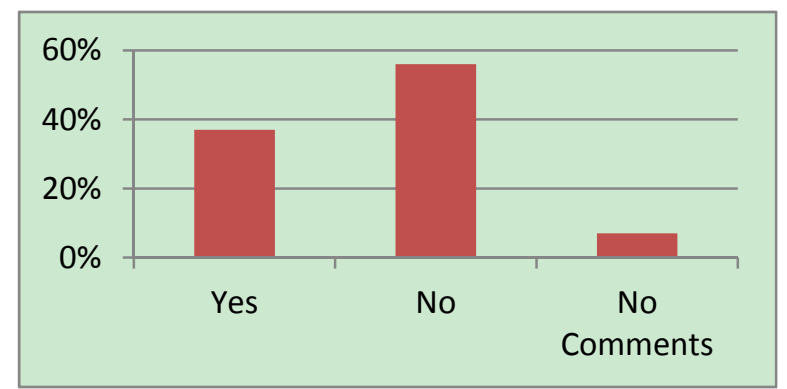

Figure 7. Witnessing DSCC campaign

Figure 7 illustrate the campaign of DSCC in the markets.37\% of the respondents DSCC campaign in the market against market irregularities. But they are not sure whether the campaign is from DSCC or TCB.On the other hand, $55 \%$ of the respondents have never seen any campaing againt mapractice in the market. $8 \%$ of the repondent do not give any comment in this regard.

\subsection{Period of Monitoring}

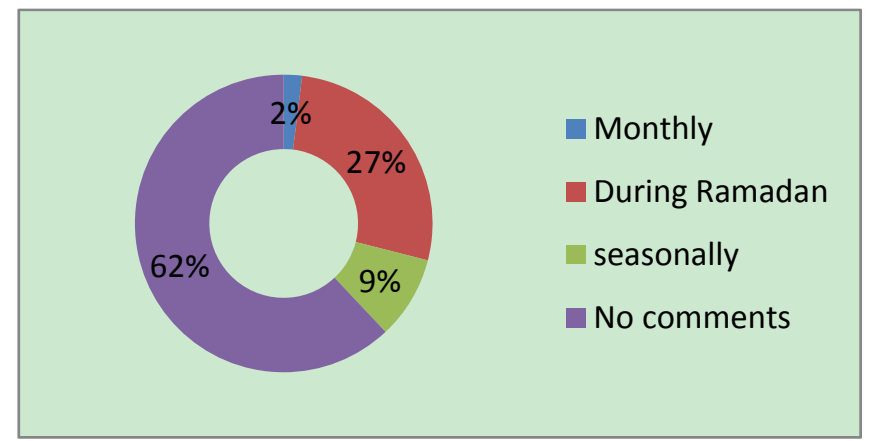

Figure 8. Period of monitoring

Figure 8 illustrates how frequently the DSCC monitor the markets under its jurisdiction. $2 \%$ of the respondents have said that the monitoring committee of DSCC come to monitor the market monthly. Whilst $9 \%$ of the respondents have said the monitoring team come seasonally. $27 \%$ of total respondent have said that the frequency of monitoring increase during Ramadan than rest of the months. Surprisingly $62 \%$ have said that they have never seen any monitoring team in the markets.

\subsection{Intensity of Punishment}

In this regard most of the respondents have never seen to punish sellers who don't follow price chart and violets the rules of DSCC, TCB or BSTI. Some of the respondents have seen to punish culprit by crocking products, damaging product etc. Few respondents have seen to impose fine from 2000-5000 taka. 


\subsection{It Is Too Hard to Complain to DSCC Monitoring Committee}

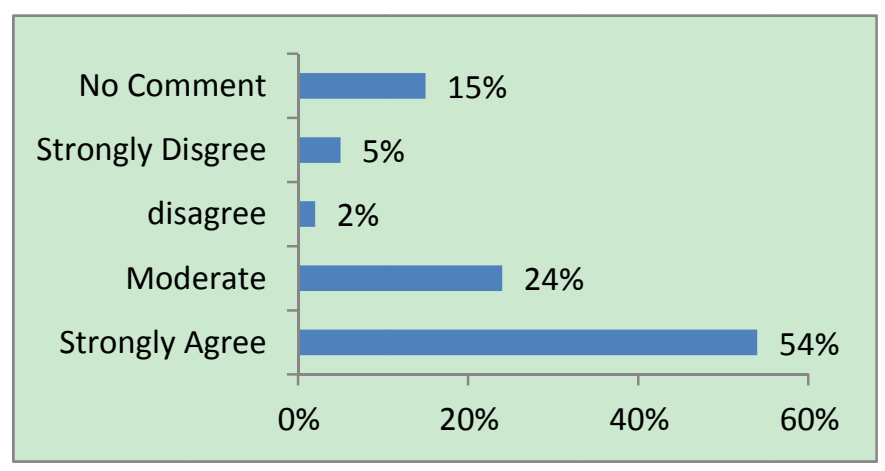

Figure 9. It is too hard to complain to DSCC monitoring committee

Most of the respondents do not know about the Bazaar monitoring system.After disclosing the matter they response spontaneously. $54 \%$ of the respondent think it is very hard to complain to the committee for market irregularities because there is nt enough accessibility for mass people. They have said that the Mayor and Councilors are not elected. As a result they do not care mass people. On the other hand, 24\% of the respondents moderately agree with the argument. $2 \%$ of of the respondents disagree with the statement. Whilst $5 \%$ of the respondents strongly disagree with the argument because they think as a public organization every one has access to the DSCC and can complain to the monitoring committee against market irregularities.

\subsection{Participation of Respondents in Human chain, Demonstration against Market Irregularities}

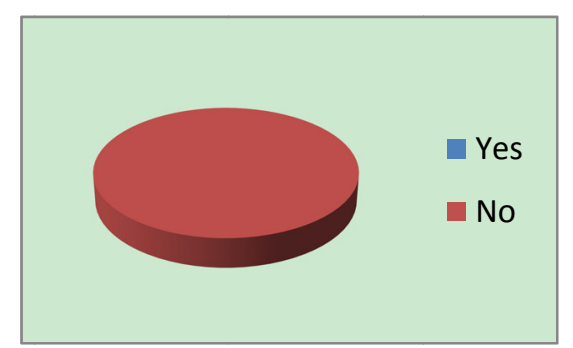

Figure 10. Participation of Respondents in Human chain, Demonstration against Market irregularities

Urfortunately no respondent participated in human chain or demonstration againts market irregularities. Acually this type of human chain is arranged by civil societies, NGOs like CAB.

\subsection{Reasons for Non Participation}

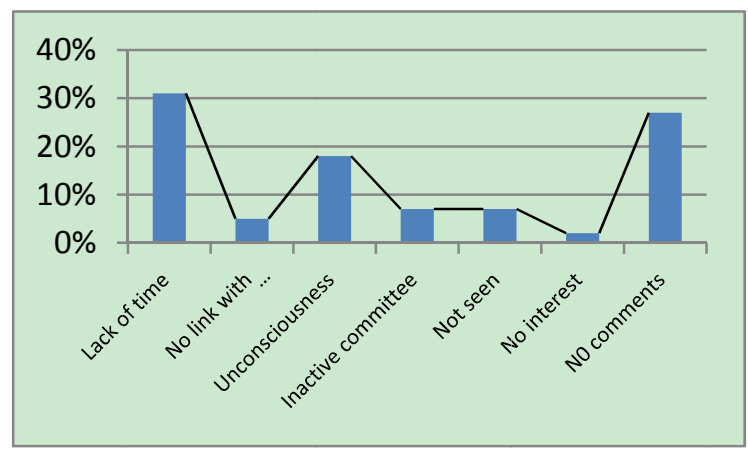

Figure 11. Reasons for non participation 
The respondents did not participate in human chain or demonstration due to varieties of reasons. $31 \%$ of the respondents are too busy to participate in human chain $.5 \%$ of the respondents have no link with any organization like $\mathrm{CAB}$ to parcipate in human chain or demonstration. $18 \%$ of the respondents did not participate due to their unconsciousness. $7 \%$ of the respondents have never seen such demonstration. Whilst $3 \%$ of the respondents have no interest to participate such suman chain or demonstration.

4.14 Sellers Follow Price Chart

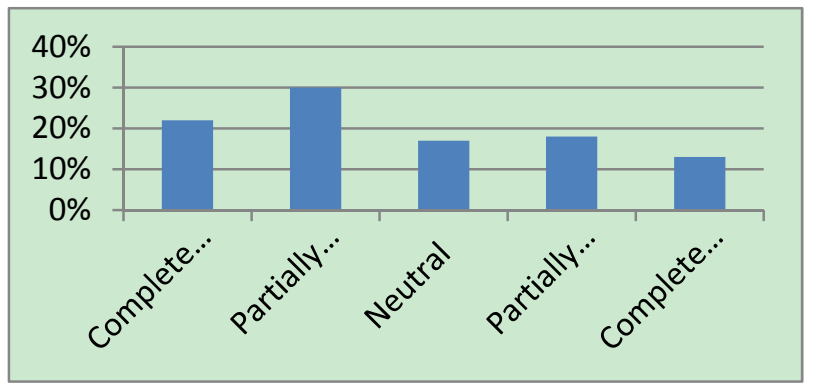

Figure 12. Sellers follow price chart

$21 \%$ of the respondents cmpletely disagree with the statement that the sellers follow the price chart. On the other hand, $30 \%$ of the respondents partially disagree whilst $17 \%$ remain neutral.18\% f the respondents partially agreed that the sellers follow the price chart to sell a product. $13 \%$ of the respondents completely agreed that the shopkeepers of grocery follow the price chart but the vegetable vendors do not follow the price chart.

\subsection{Frequency of Monitoring}

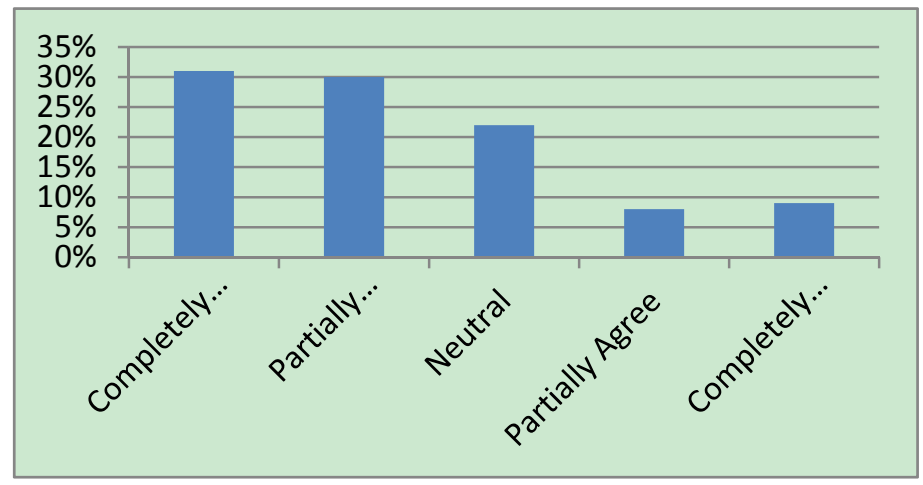

Figure 13. Frequency of monitoring

$31 \%$ of the respondents completely disagree with the argument that the market monitoring by DSCC on a regular basis. $30 \%$ of the respondents partially disagree with the argument whilst $22 \%$ remain neutral.

\subsection{Intensity of Punishment}

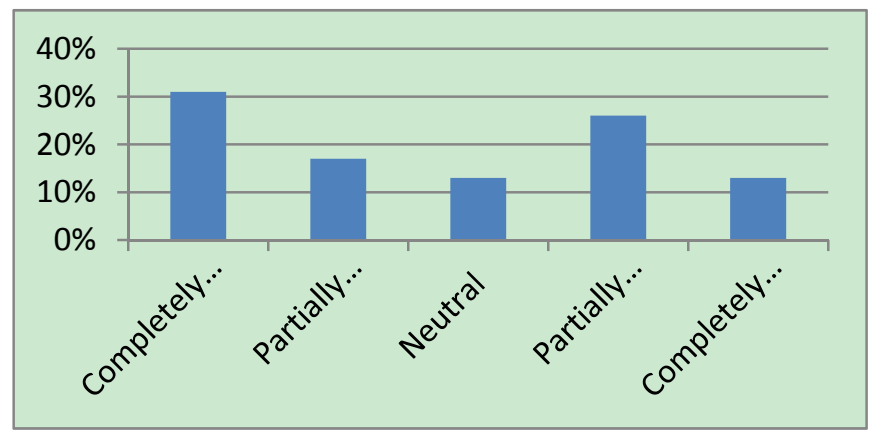

Figure 14 . Intensity of punishment 
Figure 14 Illustrate that $31 \%$ of the respondents think that the present punishment is not enough compard to fault. $17 \%$ of the respondents are partially disagree with the statement that current punishment is enough. $13 \%$ of the respondents remain neutral in this regard. $26 \%$ of the respondents are partially agree with the statement. Whilst $13 \%$ of the respondents think that current punishment is enough.

\section{Reponses of sellers}

\subsection{Existence of Price Chart}

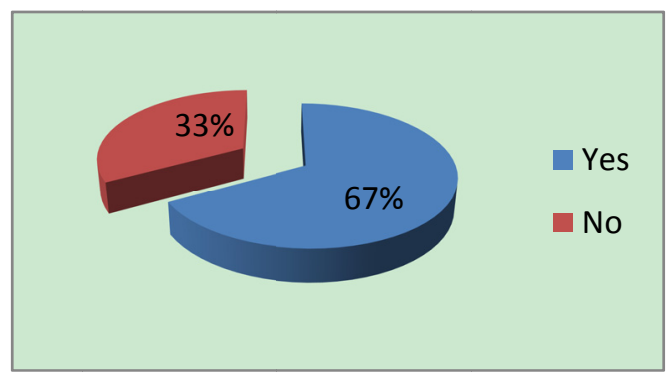

Figure 15. Existence of price chart

Figure 15 indicate that $67 \%$ of the respondent have their own price chart . This chart is monitored by TCB not DSCC.On the other hand, $33 \%$ of the respondents have no price chart in front of their shop.

\subsection{Frequency of Chart Updating}

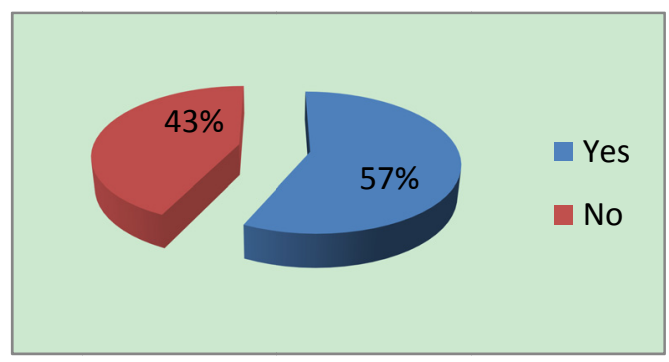

Figure 16. Frequency of chart updating

This figure 16 indicates that $57 \%$ of the respondents update their chart regularly .On the other hand,43\% of the respondents do not update their price chart on regular basis.

\subsection{Frequency of Market Monitoring}

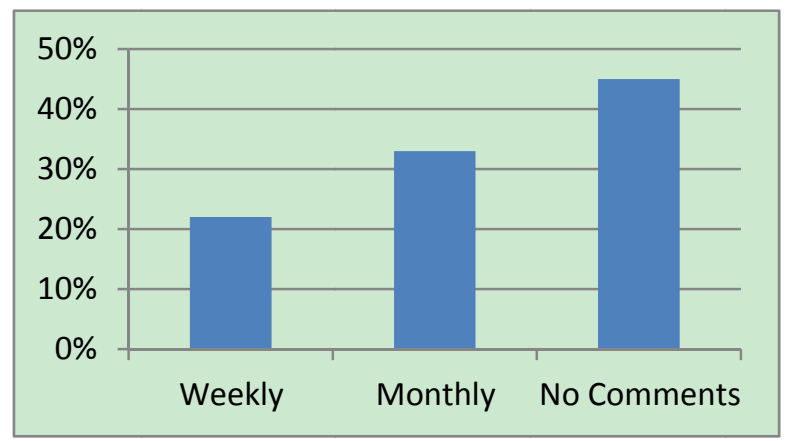

Figure 17. Frequency of market monitoring

Above figure illustrate that $22 \% \mathrm{f}$ the respondent have said that in every week market is monitored by DSCC but 
TCB is more active than DSCC.On the other hand, $33 \%$ of the respondents have said that DSCC come to monitor the market in every month. Whilst $45 \%$ of the respondents was unwilling the answer to this question.

\section{Actors of Bazaar Manipulation}

We have asked the sellers that who is responsible for bazaar manipulation / overrating and adulteration. They have identified some actors and factors of bazaar manipulation. Such as-

1) DSCC: Most of the respondents think that DSCC is highly responsible for bazaar manipulation. It is one of the prime responsibilities of City Corporation to monitor the market within its jurisdiction. But they do not monitor the market on regular basis. As a result price hiking and adulteration take place.

2) Importers and Exporters: Some respondents think importers and exporters are responsible for market manipulation. They increase the price of products intentionally. Businessmen import the product in low price but they sell it in high price.

3) Wholesale market: Wholesale market is also responsible for price hiking, adulteration, and market manipulation. When the price of a product increases in wholesale market it ultimately affects retail market. DSCC do not monitor wholesale market as a result the devil businessmen manipulate the market.

4) Ministry: Some respondents think the ministry of LGRD is also responsible for market irregularities. DSCC is responsible to ministry of LGRD but the ministry does not monitor DSCC properly. As a result there is no price chart in the market and the vendors do not follow the price chart.

5) Producer: Sometimes producers of vegetable mix formalin and other chemical in the product to get over price.

6) Politician: Politicians are also responsible for market irregularities .They have no interest for market improvement. They claim themselves as representative of people but they do not care on public interest. In the parliament they are busy with their party interest not public interest.

7) Mill factories: Mill factories are also responsible for over price. If the production costs increase it ultimately effect on market price.

8) International market: Some of the respondents think that international market manipulates our local markets.

9) Broker: Sometimes influence retail seller not to follow price chart.

10) Syndicate: A syndicate is a self-organizing group of individuals, company's corporations or entities formed to transact some specific business, to pursue or promote a shared interest. In most cases formed groups aim to scale up their profit.

\section{Factors of Market Irregularities}

1) Consumer's unconsciousness: We, the general people are unconscious about our rights. We think irregularities as regularities. We are not raising our voice against market irregularities. We are unaware about over price, price chart etc.

2) Lack of coordination among government agencies: lack of coordination among DSCC, TCB, and BSTI is also responsible for absence of price chart in the market. There is no fixed agency for market monitoring. The duties of DSCC, TCB and BSTI regarding market monitoring are not clear. Overlapping of duties is also responsible for ineffective monitoring system.

3) Corruption: Corruption is a national problem of our country. Corruption is one of the common characteristics of public organization .Corrupted officials of DSCC, TCB and BSTI are mainly responsible for market irregularities. They take cash and kind from businessmen for their inactive role regarding market monitoring.

4) Unelected mayor and councilors: There is no legal mayor and councilors in DSCC.As a result the bazaar monitoring committee is in effective. Some of the respondents think that as the administrators are not elected they are not bound to serve the people. They do not visit markets to protect the right of city dwellers.

5) Lack of manpower in DSCC: Some of the respondents think that the manpower of DSCC is not enough or insufficient to monitor all the markets under DSCC jurisdiction.

6) Lack of government willingness: Finally all the respondents agreed that government unwillingness 
is responsible for absence of price chart in the markets .Government do not want to lose his popularity to the businessmen.

\section{Some Realities Reveled}

In case market monitoring there are mainly two parties involved such as buyers and sellers .Sellers have more control and authority over the buyers. The buyers suffer from less bargaining capacity compared to sellers. As a result, the sellers are not very open to disclose all the facts. On the other hand, there are lack of coordination among DSCC, TCB and BSTI. So building coordination among the public agencies are very important.

\section{Findings}

Market monitoring is one of the basic functions of DSCC. But most of the people do not know about the monitoring system of DSCC. It is the mandatory function of DSCC to display a price chart in front of market under its jurisdiction. But unfortunately one a few markets have this price chart. The price of the products is not updated by DSCC on regular basis. Most of the people think that during holy Ramadan of frequency of monitoring increase due to huge media report. Rest of the months the sellers do not care about chart because of irregular monitoring.

Some vendors have displayed price chart of some commodities in front of their shop from their own interest.TCB and BSTI come to monitor the price chart of groceries, expires products and voucher of the products. But DSCC do not come to monitor the market especially price chart under its jurisdiction.

In the modern capitalized world everyone is hanker after money. As a country of mixed economy the people of Bangladesh are also hankering after money .City dwellers are busy with their business, service and others activities. They don't have much time to spend in the kitchen market. The purchasing power of people has been increased. Due to available money in their pocket they don't bargain with sellers to purchase a product. People are willing to spend their time, labor, money and intelligence in the capital market not in the kitchen market. Even they don't care about monitoring system of public organization like DSCC.

Most of the people of our country are unconscious about their rights in the market place. Surprisingly, educated persons are also unaware about their rights. Some of our respondents were from DU, BUET, DMCH (teachers and students). They are also unaware about following price chart and taking voucher. They even don't know about the monitoring system of DSCC. They have a stereotype that the monitoring committee of DSCC is inactive, ineffective and inefficient. As a result they don't care about price chart and taking voucher from shopkeepers.

Most of the markets are dirty especially kitchen market. Stink out is a common phenomenon in our country .Due to unfavorable environment consumer are discouraged to spend much time in the kitchen market. They feel indifferent to see the price of a product on the price chart due to clay, dirty water and gathering in the kitchen market. Consumer's busyness is the prime reason of not following price chart.

Most of the people think that they are some actors and factors of such irregularities. The actors are ministry, syndicates, politicians, importers and exporters, international market, mill factories, producers and finally the staffs of public organization like DSCC, TCB, BSTI, and DPHE. The common factors are lack of coordination among the public organizations, consumer's unconsciousness, lack of political commitment, lack of man power in public organizations.

Corruption is one of the prime reasons for ineffective bazaar monitoring system. Corrupted staffs of DSCC take cash and kind from businessmen not to monitor the market. As a result, the retailers of kitchen market get chance to violate the rules of market. They also get chance for price hiking and products adulteration.

We observed that there was a chart in New Market bazaar but there were no chart in other markets(Annanda Bazaar,Polashi Bazaar, Hatirpool Bazaar).We have visited the markets two consecutive days but we observed that the price chart was not updated. We also observed that sellers were not following the price chart. The retailers were claiming over price then enlisted price.

Finally it can be said that the market monitoring committee of DSCC is inactive and most of the markets have no price chart from DSCC. Though some of the markets have price chart but it is not updated regularly. And most of the buyers and sellers don't follow the price chart. The monitoring system is not effective but during holy Ramadan it works more effectively than rest of the years.

\section{Recommendations}

Now I would like to give some recommendations to improve the Bazaar monitoring system of DSCC and how to protect the citizens' rights in the market place. Such as- 
1) DSCC should monitor the markets especially kitchen markets under its jurisdiction regularly.

2) In every kitchen markets there should be a price char in front of markets.

3) The price chart should update regularly.

4) The Bazaar monitoring standing committee of DSCC should be strengthen.

5) The consciousness of city dwellers should be strengthen abut their rights through seminar , campaign, leaflet, booklet etc.

6) Punishment for culprit should be increased in the market.

7) Access to DSCC market monitoring standing committee should be easy.

8) Online complain system should be introduced in DSCC.

9) Corrupted officials of DSCC, TCB and BSTI should be dismissed.

10) The government should strengthen TCB, BSTI in accordance with the demand of people.

11) Appropriate implementation of "competition law" to root out syndicates.

12) The functions of Bazaar monitoring committee should be clear.

13) The government should keep harmony with international markets to raise the prices of commodities.

14) Continuous meeting with concern agencies should be arranged to control the market price.

15) According to the government election manifesto a "National Price Commission" should formulate and implement.

16) Finally political will of the government should increase to stop irregularities in the kitchen markets.

\section{Conclusion}

Bazaar monitoring system is an important phenomenon for every country like Bangladesh. Without proper Bazaar monitoring system, irregularities and mismanagement exist in a Bazaar. A kitchen market is one of the most essential markets where everyone needs to go every day. So, proper monitoring system of kitchen market and application of existing rules, regulations on this market are utmost necessary. In case of Dhaka city, Dhaka South City Corporation (DSCC) must play the most significant role in case of kitchen market monitoring system. DSCC along with other concerned market monitoring authorities (TCB, CAB, NGOs, BSTI, and CBA) should monitor the kitchen market on a regular basis. If they monitor every kitchen market and emphasis on proper implication of laws, and legal procedures, it will be helpful for the common people to buy different items in a reasonable price. Concerned authority must focus on proper display of different food items charts according to the price fixed by DSCC. It is helpful for people because they need not to bargain with the sellers to reduce the price. On the other hand sellers don't get high price compare to actual price. Another positive impact of Bazaar monitoring system is it ensures the proper quality of vegetables, fish, meat and other items. When DSCC and its concerned officials monitor market in a regular basis, sellers become alert to ensure the quality of different vegetables, fish, meat and other items. They become frightened to use chemical such as "formalin". Formalin and other toxic chemical are so much harmful for human body and it causes cancer. Only proper market monitoring system can save time, money, energy of buyers and bitter experience of bargaining between buyers and sellers. So, proper Bazaar monitoring system (Kitchen market) by DSCC is really helpful for common people. Therefore DSCC should focus on proper Bazaar monitoring system to ensure quality and quantity of different food items and to meet the proper public demand.

\section{References}

Consumers' right protection act, (2009).

Government of the Peoples Republic, Information Commission Bangladesh, 2010.

http://en.wikipedia.org/wiki/Dhaka_City_Corporation

http://www.acer.europa.eu/Electricity/Market\%20monitoring/Pages/default.aspx

http://www.consumerbd.org/

http://www.dhakasouthcity.gov.bd/

http://www.dhakasouthcity.gov.bd/markets/index.html

http://www.dncc.gov.bd/act-rules/local-government-city-corporation-amended-act.html 
http://www.dncrp.gov.bd/

http://www.localgovjamaica.gov.jm/localauthorities.aspx?c=function

Kreta-Bhokta andoloner sharuph, (2007), CAB: Dhaka.

Local Government (City corporation) act, (2009).

The Dhaka City Corporation ( Amendment ) Act, 1993.

The Dhaka Municipal Corporation Ordinance, 1983.

The Right to Information Act,2009, Dhaka.

Trading Corporation Order, (1972).

UNDP. (1996). Local Government in Bangladesh: An Agenda for Governance, Prepared for the Government of Bangladesh. Dhaka: United Nations Development Program (UNDP).

\section{Copyrights}

Copyright for this article is retained by the author(s), with first publication rights granted to the journal.

This is an open-access article distributed under the terms and conditions of the Creative Commons Attribution license (http://creativecommons.org/licenses/by/4.0/). 